\title{
ANALISIS FAKTOR - FAKTOR YANG MEMPENGARUHI EKSPOR TEKSTIL DI INDONESIA TAHUN 2005 - 2009
}

\author{
Oleh: \\ Mey Richa Madya Lestari \\ Staff Wisata Bahari Lamongan \\ E-mail/No. Hp:mey_rm@yahoo.co.id/-
}

\begin{abstract}
The type of the research was descriptive quantitative, entitled "Analysis of Factors - Factors Affecting the Export of Textile in Indonesia in 2005.1-2009.4". In this study, the researcher took the hypothesis that there were effect between PDB, Exchange Rate and Inflation on Textile Exports in Indonesia in 2005.1 2009.4. The analysis tools used a statistical test approach was called the test of significance, the decision to accept and reject Ho made on the basis of statistical values ( $t$ test and $F$ test). From the data analysis which has been conducted simultaneously indicates that the variable exchange rates had a more significant outcome of the Textiles Export. This could be seen from the significance, namely PDB variable (2.430), Exchange Rates (-3.039), and Inflation (1.944). Besides, it could also be seen from the $F$ test, which $F_{\text {count }}>F_{\text {table }}$ that was about $4.402>$ 2.28 .
\end{abstract}

Keywords: export tekstil, PDB, exchange rates, and inflation.

\begin{abstract}
Abstrak
Penelitian ini adalah jenis penelitian yang bersifat deskriptif kuantitatif yang berjudul "Analisis Faktor - Faktor yang Mempengaruhi Ekspor Tekstil di Indonesia tahun 2005.1 sampai 2009.4. Dalam penelitian ini, penulis mengambil hipotesa bahwa Diduga terdapat pengaruh antara PDB, Nilai Tukar dan Inflasi di Indonesia tahun 2005.1 - 2009.4 Alat analisis yang digunakan adalah dengan menggunakan pendekatan pengujian statistik yang disebut dengan uji signifikasi, keputusan untuk menerima dan menolak Ho dibuat atas dasar nilai statistik (uji $t$ dan uji F). Dari analisa data yang telah dilakukan secara serentak menunjukkan bahwa variabel Kurs Tukar memiliki hasil yang lebih signifikan terhadap Ekspor Tekstil. Hal ini dapat dilihat dari signifikansinya, yaitu variabel PDB $(2,430)$, Kurs Tukar sebesar $(-3,039)$ dan Inflasi $(1,944)$. Selain itu juga dapat dilihat dari uji $F$, yang mana $F_{\text {hitung }}>F_{\text {tabel }}$ yaitu sebesar 4,402 > 2,28.
\end{abstract}

Kata Kunci: Ekspor Tekstil, PDB, Nilai Tukar dan Inflasi

PENDAHULUAN

Hingga saat ini, industri Tekstil

dan Produk Tekstil Indonesia menghadapi berbagai masalah.

Masalah-masalah tersebut diantaranya

adalah biaya energi yang mahal, 
infrastruktur pelabuhan yang belum kondusif, mesin-mesin pertekstilan yang sebagian besar sudah sangat tua, dan maraknya produk impor ilegal terutama dari China. Berbagai permasalahan tersebut menyebabkan Industri TPT Indonesia berjalan dengan kondisi yang kurang sehat. Biaya operasional menjadi relatif mahal, namun dengan produktivitas yang relatif rendah. Dengan kondisi yang cukup berat tersebut, produk TPT Indonesia masih berhasil mendapat tempat yang cukup baik di pasar luar negeri, bahkan memiliki daya saing yang cukup tinggi di pasar internasional. Ini terbukti dari cukup besarnya kontribusi devisa yang dihasilkan dari sektor ini dari tahun ke tahun maupun kontribusi Indonesia terhadap perdagangan TPT internasional dibanding negara-negara eksportir lainnya.

Arah industri TPT ini merupakan jawaban terhadap kerentanan industri akibat ketergantungan yang tinggi terhadap pasar-pasar tradisional untuk ekspor, sekaligus untuk mengisi pasar domestik yang sangat potensial tetapi masih terabaikan.
Berdasarkan penelitian yang dilakukan oleh Dhayanti (2006) meneliti tentang Analisis FaktorFaktor yang Mempengaruhi Ekspor Industri Manufaktur Berbasis Kayu di Kalimantan Timur tahun 1997-2003. Dalam Penelitian tersebut peneliti menggunakan variabel output industri manufaktur, nilai tukar rupiah terhadap dollar, PDRB dan nilai ekspor, dimana peneliti menggunakan alat analisis regresi linear berganda. Adapun hasil yang diperoleh menyebutkan bahwa: Ouput industri manufaktur berbasis kayu berpengaruh positif dan signifikan terhadap nilai ekspor sektor industri manufaktur berbasis kayu di Kalimantan Timur dengan koefisien regresi sebesar 0,600 artinya kenaikan output industri manufaktur berbasis kayu akan diikuti kenaikan nilai ekspor di sektor industri manufaktur berbasis kayu. Nilai tukar rupiah terhadap dollar U.S berpengaruh negatif dan tidak signifikan terhadap terhadap nilai ekspor sektor industri kayu di Kalimantan Timur dengan koefisien regresi $-0,448$ artinya apabila nilai tukar $\mathrm{Rp} / \$$ naik maka akan mengakibatkan penurunan nialai ekspor sektor industri manufaktur 
berbasis kayu. PDRB berpengaruh positif dan signifikan terhadap nilai ekspor sektor industri manufaktur berbasis kayu di Kalimantan Timur dengan koefisien regresi sebesar 1,456 artinya kenaikan PDRB akan diikuti oleh kenaikan nilai ekspor sektor industri manufaktur berbasis kayu.

Peranan ekspor dalam
pembangunan ekonomi menurut
pandangan David Ricardo adalah
apabila suatu negara sudah mencapai
tingkat kesempatan kerja penuh,
perdagangan luar negeri
memungkinkannya mencapai tingkat
konsumsi yang lebih tinggi daripada
yang mungkin dicapai tanpa adanya
kegiatan tersebut. Sedangkan peranan
ekspor dalam pembangunan ekonomi
menurut Adam Smith dan Mill adalah
adanya hubungan ekonomi dan
perdagangan dengan luar negeri yaitu,
memungkinkan suatu negara
memperluas pasar dari hasil-hasil
produksinya dan memungkinkan
negara tersebut menggunakan
teknologi yang dikembangkan di luar
negeri yang lebih baik keadaannya
daripada yang terdapat di dalam
negeri.

Kebutuhan dana pembangunan yang semakin besar, kualitas sumber daya manusia yang masih perlu ditingkatkan, sarana dan prasarana yang kurang memenuhi sektor industri, ketergantungan impor barang modal dan bahan baku yang masih tinggi, struktur ekspor yang masih bertumpu pada beberapa komoditi, iklim investasi atau usaha yang masih kurang kondusif serta penguasaan teknologi yang masih perlu ditingkatkan adalah masalah-masalah pokok yang dihadapi dalam negeri. Peranan ekspor non migas menjadi sangat penting, terlihat dari perolehan devisa yang menunjukkan prestasi cukup meningkat. Kecemerlangan ekspor non migas ini harus dipertahankan, mengingat perdagangan khususnya ekspor kini telah menjadi mesin pemicu pertumbuhan ekonomi (Engine of Economic Growth) Indonesia.

Variabel yang memicu permintaan barang-barang luar negeri juga berasal dari nilai tukar. Nilai tukar yang berubah-ubah akan berpengaruh terhadap permintaan barang-barang luar negeri. Apabila kurs mata uang suatu negara naik (depresiasi) maka dari sisi pandang 
orang di luar negeri harga barang tersebut menjadi lebih mahal sehingga mengakibatkan mereka beralih kepada barang-barang yang harganya lebih murah. Hal ini pula yang pada akhirnya akan mengurangi ekspor dari negara tersebut. Demikian pula sebaliknya apabila kurs mata uang suatu negara turun (apresiasi), maka akan meningkatkan daya saing barang-barang yang di ekspor di pasaran internasional sehingga akan meningkatkan ekspor. Berdasarkan Marshall-Lerner condition, yang mana bahwa jumlah elastisitas harga dari permintaan ekspor dan impor negara bagian harus melebihi elastisitas keseluruhan. Depresiasi mata uang domestik akan mendorong neraca transaksi berjalan. Perhitungan empiris menunjukkan bahwa Marshall-Lerner condition dapat diterapkan di berbagai negara, tetapi setelah mencapai periode yang dijalani telah cukup panjang untuk memastikan bahwa kuantitas ekspor dan impor dapat menyesuaikan dengan perubahan harga relatif.

\section{METODOLOGI PENELITIAN}

Penelitian ini akan meneliti dan menganalisis faktor-faktor yang mempengaruhi ekspor industri tekstil di Indonesia periode 2005.1 - 2009.4. Berdasarkan tujuan penelitian yang telah ditetapkan, maka jenis penelitian ini adalah penelitian deskriptif kuantitatif. Untuk mengetahui ada tidaknya pengaruh antara variabel bebas dengan variabel terikat maka harus dilakukan analisa data dengan menggunakan regresi berganda dengan menggunakan uji F, uji T dan uji asumsi klasik.

\section{PEMBAHASAN}

Berdasarkan hasil regresi pada tabel 1, dapat diinterprestasikan sebagai berikut: pertama, $\beta_{0}=$ 17.539; Berarti pada saat PDB, Nilai Tukar dan Inflasi sama dengan nol atau konstan, maka besarnya jumlah $\mathrm{Y}=3.459^{\circ}$ kedua, $\beta_{1}=0.150$; Berarti koefisien regresi variabel Pendapatan Domestik Bruto (PDB) $\left(\mathrm{X}_{1}\right)$ sebesar 0.150 berarti ada pengaruh positif antara Pendapatan Domestik Bruto (PDB) terhadap ekspor tekstil sebesar 0.150. Jadi, apabila Pendapatan Domestik Bruto (PDB) $\left(\mathrm{X}_{1}\right)$ naik sebesar $1 \%$ maka ekspor tekstil (Y) akan naik sebesar $15 \%$. Sebaliknya, apabila Pendapatan Domestik Bruto (PDB) $\left(\mathrm{X}_{1}\right)$ turun sebesar $1 \%$ maka 
ekspor tekstil (Y) akan turun sebesar lain tetap.

$15 \%$ dengan asumsi variabel yang

Tabel 1. Hasil Regresi Linear Linear Berganda

\begin{tabular}{|c|c|c|c|c|}
\hline \multicolumn{5}{|l|}{ Dependent Variable: EKSPOR } \\
\hline \multicolumn{5}{|l|}{ Method: Least Squares } \\
\hline \multicolumn{5}{|l|}{ Date: $05 / 11 / 11$ Time: 08:29 } \\
\hline \multicolumn{5}{|l|}{ Sample: $2005: 12009: 4$} \\
\hline \multicolumn{5}{|l|}{ Included observations: 20} \\
\hline Variable & Coefficient & Std. Error & t-Statistic & Prob. \\
\hline $\mathrm{C}$ & 17.53875 & 1.999779 & 8.770346 & 0.0000 \\
\hline PDB & 0.150154 & 0.065284 & 2.300008 & 0.0352 \\
\hline NT & -0.661809 & 0.223934 & -2.955372 & 0.0093 \\
\hline INFLASI & 0.007284 & 0.003944 & 1.846779 & 0.0834 \\
\hline \multirow{2}{*}{$\begin{array}{l}\text { R-squared } \\
\text { Adiusted R-squared }\end{array}$} & 0.441810 & \multicolumn{2}{|c|}{ Mean dependent var } & 13.60782 \\
\hline & 0.337149 & \multicolumn{2}{|c|}{ S.D. dependent var } & 0.080384 \\
\hline S.E. of regression & 0.065445 & \multicolumn{2}{|c|}{ Akaike info criterion } & -2.438344 \\
\hline Sum squared resid & 0.068530 & \multicolumn{2}{|c|}{ Schwarz criterion } & -2.239197 \\
\hline Log likelihood & 28.38344 & \multicolumn{2}{|c|}{ F-statistic } & 4.221359 \\
\hline Durbin-Watson stat & 2.889173 & \multicolumn{2}{|c|}{ Prob(F-statistic) } & 0.022301 \\
\hline
\end{tabular}

Sumber : Eviews data diolah

Ketiga, $\beta_{2}=-0.662 ;$ Berarti

koefisien regresi variabel nilai tukar

$\left(\mathrm{X}_{2}\right)$ terhadap nilai ekspor tekstil sebesar

-0.662 , berarti ada

pengaruh negatif antara nilai tukar $\left(\mathrm{X}_{2}\right)$ terhadap ekspor tekstil sebesar 0.662. Jadi, apabila nilai tukar $\left(\mathrm{X}_{2}\right)$ naik sebesar $1 \%$ maka ekspor tekstil (Y) akan turun sebesar 66.2\%. Sebaliknya, apabila nilai tukar $\left(\mathrm{X}_{2}\right)$ turun sebesar $1 \%$ maka ekspor tekstil (Y) akan meningkat sebesar $66.2 \%$ dengan asumsi variabel yang lain tetap.

Keempat, $\beta_{3}=0.007 ;$ Berarti koefisien regresi variabel Inflasi $\left(\mathrm{X}_{3}\right)$ sebesar 0.007 berarti ada pengaruh positif antara Inflasi terhadap ekspor tekstil sebesar 0.007. Jadi, apabila Inflasi $\left(\mathrm{X}_{3}\right)$ naik sebesar $1 \%$ maka ekspor tekstil (Y) akan naik sebesar 7\%. Sebaliknya, apabila Inflasi $\left(\mathrm{X}_{3}\right)$ turun sebesar $1 \%$ maka ekspor tekstil (Y) akan turun sebesar 7\% dengan asumsi variabel yang lain tetap.

Hasil regresi tersebut menunjukkan koefisien determinasi $\left(\mathrm{R}^{2}\right)$ yaitu sebesar 0.442 atau $44.2 \%$ nilai ini berarti menunjukkan bahwa nilai ekspor tekstil dapat dijelaskan oleh variabel Pendapatan Domestik Bruto (PDB), Nilai Tukar, dan Inflasi. Sedangkan sisanya sebesar 0.558 atau $55.8 \%$ dijelaskan oleh variabel lain yang tidak termasuk dalam variabel yang peneliti teliti.

Agar mengetahui pengaruh pendapatan domestik bruto (PDB) terhadap nilai ekspor tekstil maka dilakukan analisis uji t. Hasil regresi 
menunjukkan variabel Pendapatan Domestik Bruto (PDB) $\left(\mathrm{X}_{1}\right)$ di peroleh t statistik (2.300), sedangkan untuk $\mathrm{t}$ tabel (1.746), maka dapat dijelaskan bahwa t statistik $>\mathrm{t}$ tabel atau menerima Ha dan menolak Ho. Sehingga dapat dijelaskan bahwa pengaruh Pendapatan Domestik Bruto (PDB) $\left(\mathrm{X}_{1}\right)$ terhadap Ekspor Tekstil $(Y)$ adalah signifikan dengan kata lain ada pengaruh yang positif antara variable $\mathrm{X}_{1}$ terhadap variabel $\mathrm{Y}$.

Adapun untuk variabel nilai tukar rupiah terhadap dollar U.S $\left(\mathrm{X}_{2}\right)$ di peroleh $t$ statistik (-2.955), sedangkan untuk t tabel (1.746), maka dapat disimpulkan bahwa $\mathrm{t}$ statistik > $\mathrm{t}$ tabel atau menerima $\mathrm{Ha}$ dan menolak Ho. Sehingga dapat disimpulkan bahwa pengaruh Nilai Tukar $\left(\mathrm{X}_{2}\right)$ Terhadap Ekspor Tekstil (Y) adalah signifikan dengan kata lain ada pengaruh yang negatif antara variabel $\mathrm{X}_{2}$ terhadap variabel $\mathrm{Y}$. Sedangkan untuk variabel inflasi $\left(\mathrm{X}_{3}\right)$ di peroleh $\mathrm{t}$ statistik (1.847), sedangkan untuk t tabel (1.746), maka dapat disimpulkan bahwa $\mathrm{t}$ statistik > $\mathrm{t}$ tabel atau menerima $\mathrm{Ha}$ dan menolak Ho. Sehingga dapat dijelaskan bahwa pengaruh Inflasi $\left(\mathrm{X}_{3}\right)$ terhadap Ekspor Tekstil (Y) adalah signifikan dengan kata lain ada pengaruh yang positif antara variabel $\mathrm{X}_{3}$ terhadap variabel $\mathrm{Y}$.

Selain itu, hasil regresi menunjukkan nilai $\mathrm{F}$ statistik yaitu sebesar 4.221, sedangkan untuk $\mathrm{F}$ tabel sebesar 2.28. Maka dapat dijelaskan bahwa $\mathrm{F}$ statistik $>\mathrm{F}$ Tabel atau menerima Ha dan menolak Ho. Berarti variabel bebas $\mathrm{X}_{1}, \mathrm{X}_{2}, \mathrm{X}_{3}$ (Pendapatan Domestik Bruto (PDB), Nilai Tukar dan Inflasi) berpengaruh secara serentak terhadap variabel terikat Y (Ekspor Tekstil). Model dalam regresi ini dapat dinyatakan lolos dalam uji asumsi klasik yang meliputi autokorelasi, heteroskedastisitas, dan multikolinieritas.

Menurut Mankiw (2006) Hubungan antara PDB dengan ekspor adalah positif artinya, apabila PDB suatau negara meningkat maka kapasitas produksi juga akan meningkat sehingga berpengaruh terhadap jumlah supply ekspor dan berpengaruh pada harga ekspor dimana apabila harga naik maka permintaan turun sehingga ekspor akan turun sebaliknya apabila harga turun permintaan akan meningkat sehingga ekspor akan meningkat. Hal 
ini di buktikan dengan kajian statistik yang menerangkan koefisien regresi sebesar 2.430 dan hasil perhitungan tabel diperoleh $\mathrm{t}$-stat $(2,430)>\mathrm{t}$-tabel $(1,746)$ berarti Ho ditolak dan $\mathrm{Ha}$ diterima dengan demikian bahwa PDB berpengaruh signifikan terhadap ekspor tekstil. Hal ini berarti kajian teoritis sesuai dengan pembuktian dari kajian statistik yang menyatakan PDB mempunyai pengaruh positif terhadap ekspor tekstil.

Adapun menurut MarshalLerner nilai tukar yang berubah-ubah akan berpengaruh terhadap permintaan barang-barang luar negeri. Apabila kurs mata uang suatu negara naik (depresiasi) maka dari sisi pandang orang di luar negeri harga barang tersebut menjadi lebih mahal sehingga mengakibatkan mereka beralih kepada barang-barang yang harganya lebih murah. Hal ini pula yang pada akhirnya akan mengurangi ekspor dari negara tersebut. Demikian pula sebaliknya apabila kurs mata uang suatu negara turun (apresiasi), maka akan meningkatkan daya saing barang-barang yang di ekspor di pasaran internasional sehingga akan meningkatkan ekspor. Hasil perhitungan tabel diperoleh t-stat (-
3,039) > t-tabel $(1,746)$ berarti Ho ditolak dan Ha diterima. dengan demikian bahwa kurs tukar berpengaruh signifikan dan positif terhadap ekspor tekstil.Namun hal ini tidak di buktikan dengan kajian statistik yang menerangkan koefisien regresi sebesar 3,039 menunjukan ada hubungan positif terhadap ekspor tekstil sehingga tidak sesuai dengan kajian teoritis. Hal tersebut dikarenakan para produsen tekstil masih mengandalkan bahan baku impor dari luar negeri terutama kapas. Sehingga para produsen pada saat terjadi krisis keuangan global banyak yang mengalami gulung tikar yang disebabkan biaya produksi terlampau tinggi. Hal ini berarti kajian teoritis tidak sesuai dengan pembuktian dari kajian statistik yang menyatakan kurs tukar mempunyai pengaruh positif terhadap ekspor tekstil.

Senada dengan pendapat tersebut, Boediono menyatakan hubungan inflasi dengan ekspor adalah positif yaitu apabila inflasi suatu negara meningkat maka nilai tukar akan turun sehingga ekspor meningkat. Sebaliknya apabila inflasi suatu negara turun maka nilai tukar akan naik sehingga harga barang- 
barang domestik relatif rendah dibandingkan harga barang-barang luar negeri menyebabkan ekspor mengalami penurunan. Hal ini dibuktikan dengan kajian statistik yang menerangkan koefisien regresi sebesar 2.430 dan Hasil perhitungan tabel diperoleh $\mathrm{t}$-stat $(1,944)>\mathrm{t}$-tabel $(1,746)$ berarti Ho ditolak dan $\mathrm{Ha}$ diterima dengan demikian bahwa inflasi berpengaruh signifikan terhadap ekspor tekstil. Hal ini berarti kajian teoritis sesuai dengan pembuktian dari kajian statistik yang menyatakan PDB mempunyai pengaruh positif terhadap ekspor tekstil.

\section{PENUTUP}

Perkembangan ekspor tekstil di Indonesia cukup memuaskan walaupun sempat dijuluki sunset industry dan perbankan belum mau memberikan modal kepada industri ini. Bahan baku tekstil di Indonesia masih banyak mengimpor khususnya bahan baku kapas, sehingga pada saat terjadi krisis keuangan global banyak industri tekstil yang gulung tikar.

Berdasarkan hasil estimasi dan pembahasan hasil penelitian tentang faktor - faktor yang mempengaruhi ekspor tekstil di indonesia tahun 2005.1 sampai 2009.4 dapat diambil kesimpulan bahwa PDB (X1), Kurs Tukar (X2), dan Inflasi (X3) mempunyai pengaruh positif terhadap ekspor tekstil. Adapun Kurs Tukar (X2) merupakan variabel yang paling berpengaruh terhadap ekspor tekstil.

\section{DAFTAR PUSTAKA}

Ahsyar, H. Djauri \& Amirullah. 2002. Teori dan Praktek Ekpor Impor. Malang : Graha Ilmu.

Amir, M.S. 1999. Strategi Penetapan Harga Ekspor. Jakarta : P.T. Pustaka Binaman Pressindo.

Arsyad, Lincollin, M.sc. 1987. Ekonomi Mikro. Edisi 1. Yogyakarta : BPFE

Arsyad, Lincollin, M.sc. 1992. Ekonomi Pembangunan. Edisi 3. Yogyakarta: STIE. YKPN.

Dhayanti, Wiwit Sari. 2006. Analisis Faktor-Faktor yang Mempengaruhi Ekspor Industri Manufaktur Berbasis Kayu di Kalimantan Timur tahun 1997-2003. Malang: Universitas Muhammadiyah Malang.

Deperin. 2007. Perkembangan Ekspor Tekstil di Indonesia. Jakarta

Ehrenberg, G Ronald dan Smith, S Robert. 2000. Modern Theory and Labor Public Policy 
Economics. Addison Wesley : USA

Ghozali, Imam.2001. Aplikasi Analisis Multivariate dengan Program SPSS. Semarang: Badan Penerbit Universitas Diponegoro.

Hill Hali. 1991. Investasi Asing dan Industrialisasi di Indonesia. Jakarta: LP3S.

Indonesia, Bank. 2006. Statistik Ekonomi Keuangan Indonesia Vol VIII No.3: Jakarta

\section{Statistik}

Ekonomi Keuangan Indonesia Vol IX No.7: Jakarta.

.2008. Statistik Ekonomi Keuangan Indonesia Vol X No.8: Jakarta.

.2009. Statistik Ekonomi Keuangan Indonesia Vol XI No.5: Jakarta

$$
\text { .2010. Statistik }
$$

Ekonomi Keuangan Indonesia Vol XII No.5: Jakarta

Krugman R. Paul, \& Obstfeld, Maurice. 1991. Ekonomi Internasional. Jakarta: PAUFE Universitas Indonesia dan Harper Collins Publishers.

Kuncoro, Mudrajad. 2002. Analisis Spasial dan Regional, Study Aglomerasi dan Kluster Industri Indonesia. Yogyakarta: UPP AMP YKPN.

Linder, H Peter \& Kindleberger, P. Charles. 1995. Ekonomi
Internasional. Jakarta: Erlangga.

Lineman, Hans, Djick, Pitou. Van \& Verbruggen, Harmen. 1987. Export Oriented Industrialization. Typeset by International Typesetter.

Mankiw, N. Gregory. 2000. Teori Makro Ekonomi. Edisi Keempat. Jakarta: Erlangga.

Nopirin. $1995 . \quad$ Ekonomi Internasional. Edisi Ketiga. Yogyakarta: BPFE

Nuraini, Ida.2001. Pengantar Ekonomi Mikro. Malang: Universitas Muhammadiyah Malang.

Salvator. 1994. Ekonomi Internasional. Edisi Ketiga. Jakarta: Erlangga.

1997. Ekonomi Internasional. Edisi Kelima. Jilid 1. Jakarta: Erlangga.

Sicat, Gerardo. $\mathrm{P}$ dan Arnd,H.W. 1991. Ilmu ekonomi. Jakarta: LP3S.

Soeratno. 2003. Ekonomi Mikro Pengantar. Edisi 2. Yogyakarta. STIE.

Sri Adiningsih, M.sc. 1999. Mikro Ekonomi. Edisi Pertama. Yogyakarta: BPFE.

Sugiyono. 2001. Metode Penelitian Administrasi. Bandung: CV. Alfabeta

Sukirno, Sadono. 1985. Pengantar Teori Makroekonomi. Kuala 
Lumpur, Malaysia: Lembaga Penerbit Fakultas Ekonomi Universitas Indonesia.

Team Laboratorium IESP. 2008. Modul Praktikum Ekonometrika. Edisi kelima. $\mathrm{UMM}$

http://data.tp.ac.id/dokumen/ekspor+t ekstil+indonesia http://egismy.wordpress.com/.../bagia n-ii-industri-tekstil-danproduk-tekstil-tpt-indonesia/.

http://www.metrotvnews.com/.../Eksp or-Tekstil-IndonesiaBerpeluang-Banyak-Terserap.

http://www.google.co.id/\#hl=id\&biw $=792 \&$ bih $=428 \& q=$ ekspor + te kstil+di+indonesia\&aq $=\mathrm{f} \& a q i$ $=\& \mathrm{aql}=\& \mathrm{oq}=\& \mathrm{fp}=38 \mathrm{ce} 4 \mathrm{a} 921$ Of1d052 